DOI: https://doi.org/10.31933/dijdbm.v2i6

Received: 15 October 2021, Revised: 25 October 2021, Publish: 30 Nevember 2021

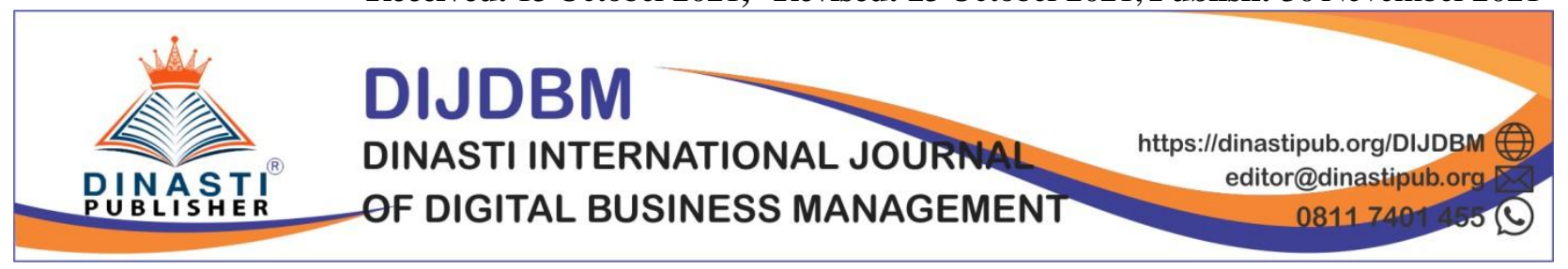

\title{
RESTAURANT MENU DESIGN MUARO NEW SAND JAMAK
}

\author{
Jusmita Weriza $^{1}$, Danyl Malisza ${ }^{2}$, Nuraeni Dahri ${ }^{3}$, Meri Susanti ${ }^{4}$ \\ 1) Ekasakti University Padang, West Sumatra, Indonesia, email.jusmitaweriza@ gmail.com \\ 2) Ekasakti University Padang, West Sumatra, Indonesia \\ 3) Ekasakti University Padang, West Sumatra, Indonesia \\ 4) Ekasakti University Padang, West Sumatra, Indonesia
}

Corresponding Author: Jusmita Weriza

\begin{abstract}
The design of this application aims to design the menu at the new Android-based Muaro restaurant as an effort to overcome the problem of an ineffective and efficient ordering system. The conventional menu ordering process affects delays and errors in reading orders by the chef. Application design using the android platform. The research method uses the System Development Life Cycle (SDLC) with a Waterfall model approach which consists of 5 stages, namely, a) planning b) analysis c) design d) implementation e) maintenance. The programming language used is PHP, and the database application uses MySql data processing. The system design tool uses the Unified Modeling Language (UML) method using 4 (four) diagrams according to design needs, namely Use Case, Activity Diagram, Class Diagram, Sequence Diagram. This android-based menu design results in a menu ordering process by consumers and knowing the total payment. This application also makes it easier for the chef to know the orders that must be made, as well as produce sales transactions that are fast, accurate, and informative. This menu application can improve menu ordering services by consumers. In general, this application can overcome various problems such as not ordering orders, errors reading orders by the chef.
\end{abstract}

Keywords: Android, UML, SDLC, Waterfall

\section{INTRODUCTION}

In the current digital trend, the community's need for technological development is very high, thus spurring the rapid development of information technology in society. The use of IT in managing and producing information has become a trend and a way of life.

The development of technology today has a great influence on the world of technology and telecommunications. Smartphone users in Indonesia are very large, according to research about 62.7\% (Director General of Information and Public Communication of the Ministry of Communication and Informatics, FH Tulung, 2013) of the Indonesian population who use it so 
that there are many emergence of various applications that provide options in improving the performance of a job, both are desktop-based, web-based to the current emergence of new applications that run on mobile. One of the many applications that appear is in the culinary field.

Restaurant is one of the culinary businesses that are much favored by business people. In the city of Padang itself the growth of the restaurant business looks very significant. With so many restaurant competition, restaurant managers must be able to understand the needs and desires of customers through good service quality. One of the restaurants in the city of Padang is the Muaro Baru Pasir Jambak restaurant.

The Muaro Baru Pasir Jambak Restaurant still provides conventional food and beverage ordering services. As in general, the process of recording orders still uses a piece of paper. In the ordering process, the waiter comes to the customer's table and records food and drink orders, then they are processed in the kitchen and then served again by the waiter.

This application is designed to simplify the ordering process (user friendly) by customers who are directly connected to the chef's section, making it easier for customers to know the total that must be paid, so as to minimize the use of time.

\section{RESEARCH METHODS}

This research uses the System Development Life Cycle (SDLC) or systems development life cycle in systems engineering and software engineering is the process of making and changing systems as well as the models and methodologies used to develop these systems. This concept generally refers to a computer or information system. SDLC is also a pattern taken to develop a software system which consists of the following stages: planning, analysis, design, implementation, testing and maintenance. (Blanchard, B. S. \& Febrycky, W. J, 2006). In the SDLC system, each part of the development is divided into several stages of work. Each of these stages has its own characteristics.

The System Development Life Cycle (SDLC) or the system development life cycle with the main steps to be used are as follows:

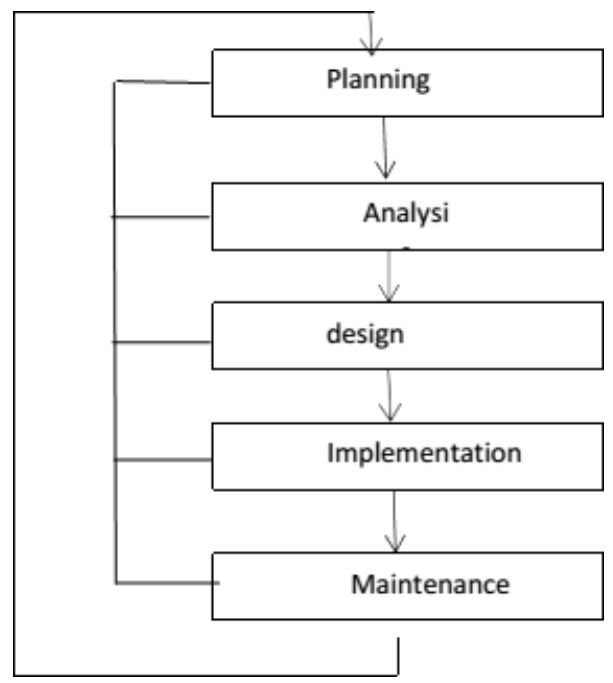

Source: Joko Dewanto, System Development Life Cycle With Several Approaches, 2012 System Development Cycle Image 
This stage is a stage that is more directed to system management and is required by an analyst in system development.

\section{DISCUSSION AND RESULTS}

System design is the development of a new system from the existing old system, problems that occur in the old system are expected to be resolved in the new system. The system design is needed as a translation stage of the system requirements needed to facilitate the work of application users (Dewanto, 2012). In designing the system requires a unified modeling language (UML) design tool.

Rosa and Salahuddin (2014), argue that UML (Unified Modeling Language) is one of the language standards that is widely used in the industrial world to define requirements, make analysis and design, and describe architecture in object-oriented programming. Meanwhile, Mulyani, 2016 said that UML (Unified Modeling Language) is a technique system development that uses a graphical language as a tool for documenting and performing system specifications.

The description of the opinion above can be concluded that UML (Unified Modeling Language) is a language that is often used to build a software system by analyzing designs and specifications in object-oriented programming. UML (Unified Modeling Language) has diagrams that are used in making object-oriented applications, including: (Rosa and Salahuddin, 2014).

\section{Use Case Diagrams}

Use Case Diagram is a model to perform (behavior) the information system to be made. Use cases are used to find out what functions are in a file

information systems and who has the right to use those functions (Rosa and Salahuddin, 2014). Here are the symbols in the use case diagram:

\section{Table of Use Case Diagram Symbols}

\begin{tabular}{|c|c|c|}
\hline Picture & Name & Description \\
\hline & Actor & $\begin{array}{l}\text { People, processes, or other systems that interact with information } \\
\text { systems that are created outside the information system that will be } \\
\text { made itself, so even though the symbol of an actor is an image of a } \\
\text { person, it is not necessarily a person; usually expressed using a } \\
\text { noun at the beginning of the actor's name phrase }\end{array}$ \\
\hline$\longrightarrow$ & Extend & $\begin{array}{l}\text { An additional use case relation to a use case is called a use case that } \\
\text { is added to stand alone even without the additional use case; similar } \\
\text { to the principle of intherince in object-oriented programming; } \\
\text { usually the additional use case has the same first name as the added } \\
\text { use case. }\end{array}$ \\
\hline & Generlization & $\begin{array}{l}\text { The relationship between generalization and specialization } \\
\text { (general-specific) between two use cases where one function is a } \\
\text { function } \\
\text { more common than others. }\end{array}$ \\
\hline & Association & $\begin{array}{l}\text { Communication between actors and use cases that participate in use } \\
\text { cases or use cases have interactions with actors }\end{array}$ \\
\hline & Use case & $\begin{array}{l}\text { The functionality provided by the system as units that exchange } \\
\text { messages between units or actors, is usually expressed by using a } \\
\text { verb at the beginning of a Use Case name phrase. }\end{array}$ \\
\hline
\end{tabular}




\section{Activity Diagram}

Activity Diagram describes the workflow (workflow) or activities of a system or business process or menu that is in the software. It should be noted that activity diagrams depict system activities not what actors do, so activities the system can perform. The following are the symbols in the activity diagram: (Rosa and Salahuddin, 2014).

\section{Table of Activity Diagram Symbols}

\begin{tabular}{|c|c|l|}
\hline Picture & Name & \multicolumn{1}{|c|}{ Description } \\
\hline & Initial state & $\begin{array}{l}\text { Initial state of system activity, an activity diagram has } \\
\text { an initial state. }\end{array}$ \\
\hline & Bctivity & $\begin{array}{l}\text { Activities carried out by the system, activities usually } \\
\text { begin with a verb }\end{array}$ \\
\hline & Merger & $\begin{array}{l}\text { Branching associations where if there is a choice the } \\
\text { activity begins with a verb }\end{array}$ \\
\hline & Final status & $\begin{array}{l}\text { The final state that the system performs, an activity } \\
\text { combined into one }\end{array}$ \\
\hline
\end{tabular}

Proposed System Use Case

Use cases are used to find out what functions are in a system and who has the right to use these functions. The following is the design of a food menu information system and food ordering at the Muaro Baru Restaurant, a use case diagram of the proposed system:

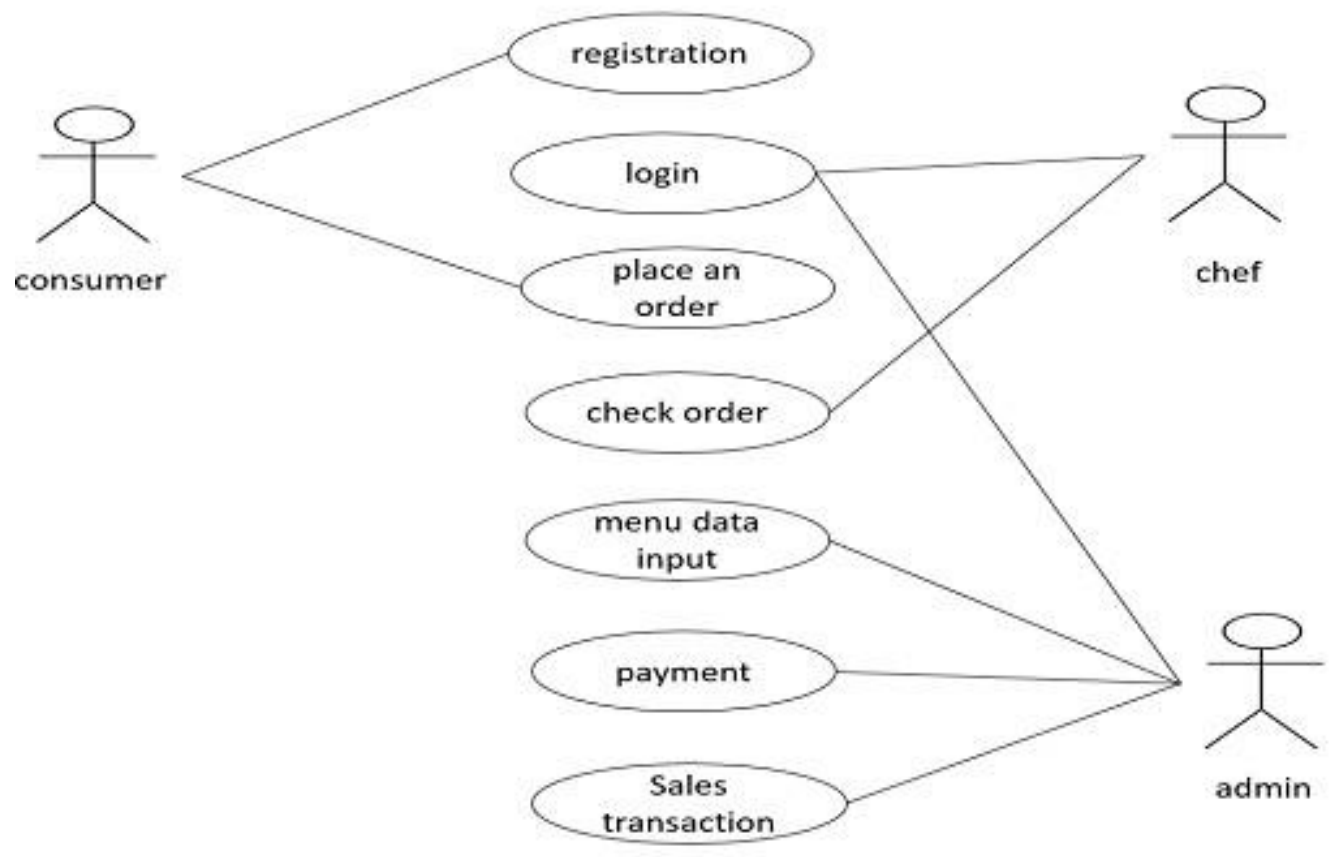

Image of Proposed System Use Case 
Based on the picture of the proposed system use case, it can be seen that there are 3 actors, namely consumers, admins, and cooks. The activities carried out by each actor are as follows:

1. Consumer activity

a. Consumers first register by entering their name, cellphone number and choosing a table number.

b. Consumers select the menu and then place an order.

2. Chef activities

a. The chef is logging in

b. Chef checking and making menu orders

c. Admin/cashier activity

d. Admin login

e. Admin input menu data

f. Admin/cashier Receive payment

g. Admin/cashier prints sales transactions

Activity Diagram Ordering (Consumer)

Activity diagram of ordering food at the new Muaro restaurant can be seen in the image below:

Image of Activity Diagram of Food Ordering

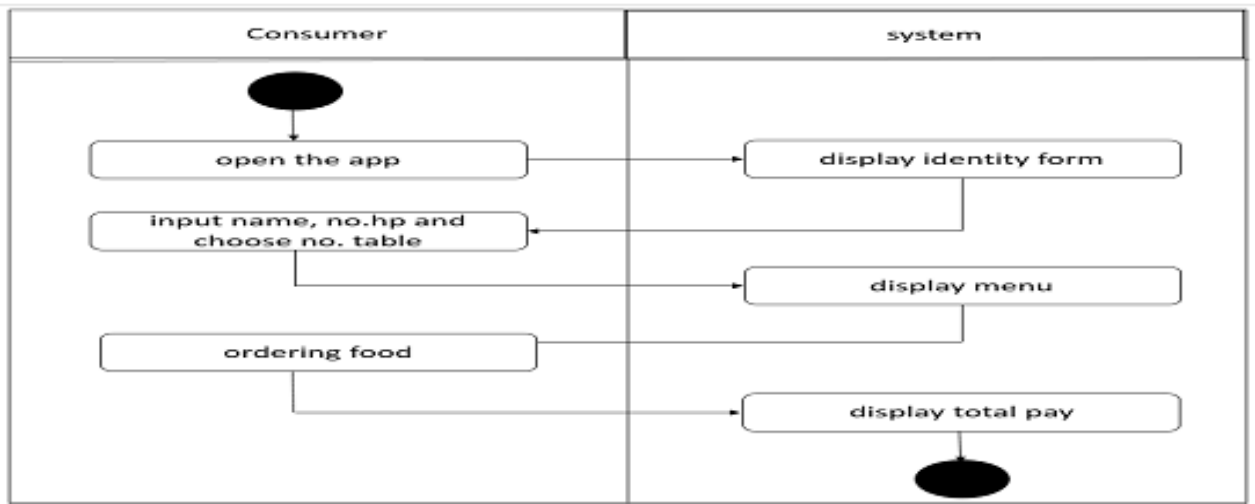

Activity Diagram Login Process (cashier/admin, chef)

Activity diagram of the login process for the cashier / admin and chef at the new Muaro restaurant can be seen in the image below

Image Activity Diagram Login Process

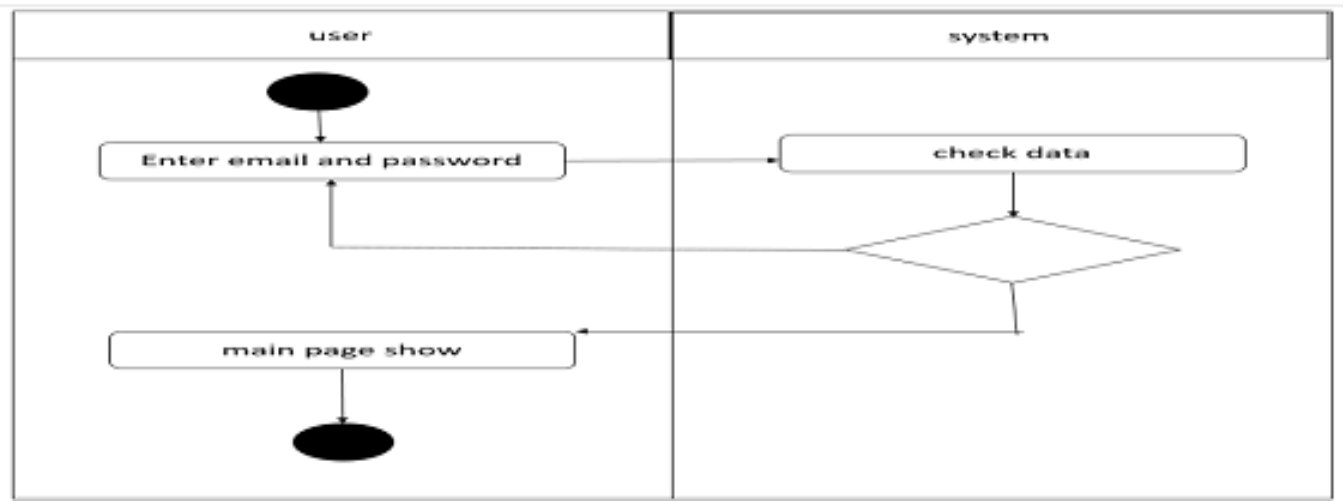


Activity Diagram of the Checking Process for the Chef

Activity diagram of the checking process for the chef at the new Muaro restaurant can be seen in the image below:

Picture of the checking process activity diagram on the chef

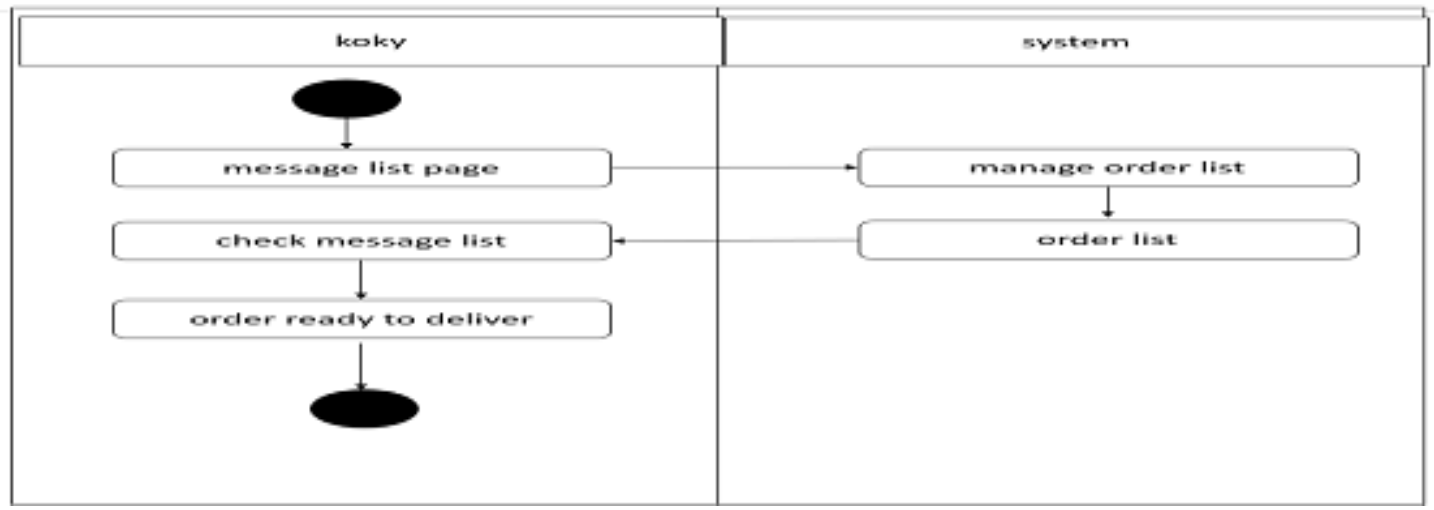

Activity Diagram in Admin (Cashier)

The admin activity diagram (cashier) at the new Muaro restaurant can be seen in the image below:

Image of activity diagram on admin (cashier)

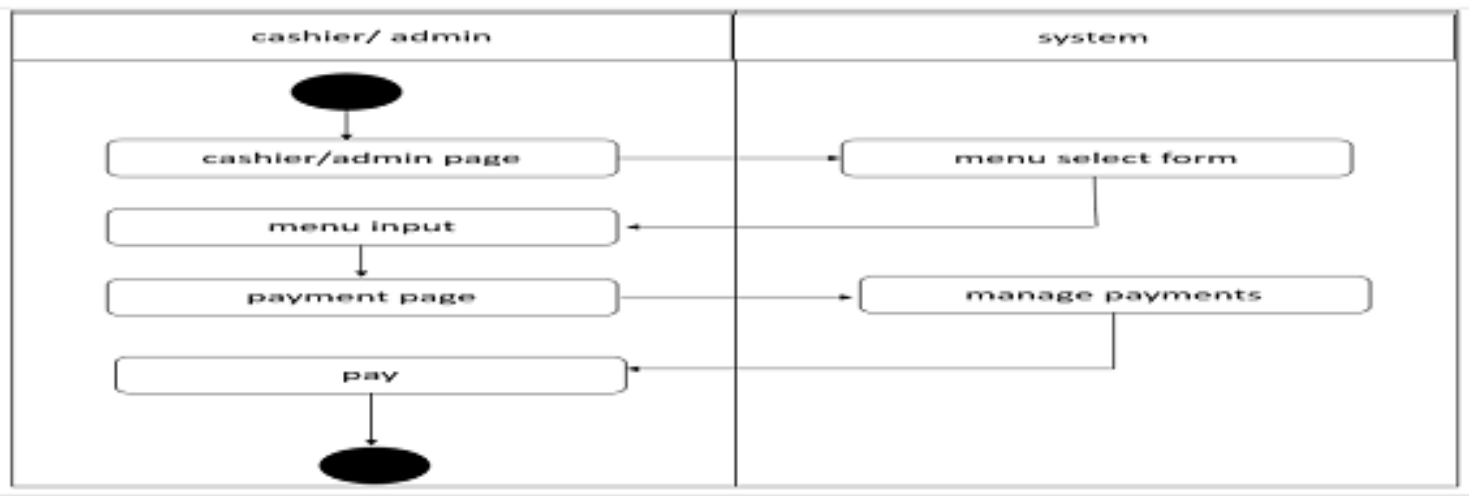

Activity Diagram of Admin/Cashier Sales Transactions

Activity diagram of sales transactions for the admin (cashier) at the new Muaro restaurant can be seen in the image below:

Image of sales transaction activity diagram for admin (cashier)

\begin{tabular}{|l|l|l|}
\hline \multicolumn{2}{|c|}{ cashier/ admin } & \multicolumn{2}{|c|}{ system } \\
\hline transaction historvpage & \\
\hline print transaction report & \\
\hline
\end{tabular}




\section{CONCLUSION}

Based on the analysis and the results of the discussion in the Menu Design of the Muaro Baru Pasir Jambak Restaurant based on Android, the author concludes:

1. The design of this application can overcome the problem of human error, unordered orders made as a result of piles of order records and errors in reading orders by the chef.

2. This design shows the customer the total paid and the table number.

\section{BIBLIOGRAPHY}

Al-Bahra Bin Ladjamudin. 2013. "Information system analysis and design". Chapter II Literature $\begin{array}{lllll}\text { Review } & 2.1 & \text { Information } & \text { Systems. Available }\end{array}$ https://Repository.Bsi.Ac.Id/Index.Php/Unduh/Item/89/File_10-Chapter-II-LandasanTeori.Pdf.

Brady and Loonam. 2010. "The Bethesda Ranotana GMIM Member Information System Using the CodeIgniter Framework" E-Journal of Electrical and Computer Engineering vol.5 no 4 January-March 2016. Available at https://ejournal.unsrat.ac.id.

Betha, Sidiq, 2014. "Web Programming with PHP". Indonesia Journal on information systems. Available at http://ijiswiratama.org/inde.php/home/article/download/35/26

Davies, 2015. "The Role of Information Technology in the Era of the Industrial Revolution 4.0". Kompasiana.com articles. Available at https://www.kompasiana.com.

Fitriani, Rani (2014). "Information System Development” [Online] is available at sisteminformation.html.

Sugiarti. 2013. "Web-Based Application for Data Processing of Official Travel at the Department of Manpower and Transmigration of Lampung Province". Scientific Work of Informatics Management Students. Available at http://eprints.jeb.polinela.ac.id/332/1/jurnal\%20Andreas\%20Hari\%20H erlambang\%2015753007.pdf

Sugiyono, 2005. "Performance of BKM Mekar Sari in Realizing PNM Priority Areas in Pati Lor Exit, Pati District, Pati Regency". Research Method Article. Available at https://eprints.uny.ac.id

Sugiarti, Yuni, S.T., M. Kom. 2013. "UML (Unified Modeling Language) Generated VB6 Analysis and

Design". https://eprints.uny.ac.id/20529/1/Kusumaningati\%20Sulistya\%20Ward hani10520241007.pdf.

Zefriyenni and Santoso. 2015. "Designing an Integrated Medical Record Information System in an Effort to Improve Services for the Handsome Mental Hospital Prov. Riau". IntraTeach Journal. https://www.journal.amikmahaputra.ac.id/index.php/JIT/article/view/3. 